\title{
Econometric analysis of the capital structure of oil and gas companies in Russia
}

\author{
Irina Filimonova ${ }^{1 *}$, Anna Komarova $^{1}$, and Anastasia Chebotareva $^{2}$ \\ ${ }^{1}$ Institue of Economics and Organization of Industrial Production SB RAS, Novosibirsk, 630090, \\ Russia \\ ${ }^{2}$ Trofimuk Institute of Petroleum Geology and Geophysics SB RAS, Novosibirsk, 630090, Russia
}

\begin{abstract}
The article is devoted to an in-depth study of the capital structure of oil and gas companies in Russia and the identification of key factors that affect the ratio of equity and debt capital. In the context of ongoing technological sanctions, an increase in the share of hydrocarbon production in the framework of capital-intensive projects for the development of hard-to-recover reserves and high depreciation of fixed assets, the need for investment, and justification of an effective borrowing strategy is sharpening.
\end{abstract}

\section{Introduction}

The oil and gas industry of Russia over the past two decades has been the main part of the Russian economy. Despite the slowdown in the growth rate of the industry in 2020 due to the crisis and the coronavirus pandemic, at the end of 2019 , OGC provided $45 \%$ of federal budget revenues, $60 \%$ of export earnings, made it possible to form a record volume of the National Wealth Fund (14 trillion rubles) and to significantly replenish gold and foreign exchange reserves.

At the same time, structural changes are taking place in the geography of oil and gas production - a shift to the regions of the Arctic zone, to Eastern Siberia and the Far East, as well as a deterioration in the quality characteristics of the extracted raw materials and mining and geological conditions of production. So, despite the increase in oil production in 2019 to 561.1 million tons, which corresponds to the maximum production in the territory of the RSFSR since 1988 (570 million tons), the share of hard-to-recover oil amounted to $55 \%$ of the total production volume.

Therefore, companies have a need to attract additional investment and expand fixed assets to improve the reliability of work and production efficiency.

Capital is a key parameter of a company's activity in any industry, it underlies the process of generating profits. The capital structure reflects the company's policy in the debt capital market, and also indicates its stability and efficiency in the use of equity capital, which helps investors and shareholders to monitor the state of the enterprise and make informed decisions. Depending on the industry, the patterns of the formation of borrowed capital, the accumulation and use of equity capital, as well as their ratio, also vary $[1,2]$.

${ }^{*}$ Corresponding author: filimonovaiv@list.ru 
Thus, an in-depth study of the peculiarities of capital formation in the oil and gas industry is of scientific interest due to changes in the internal and external environment of companies' activities associated with a deterioration in the quality of the resources and reserves base, changes in the geography of production, decarbonization of the economy, sanctions, unfavorable price conditions, taxation, etc. All of these factors actualize the search for a solution to the problem of choosing not only the sources of financing necessary either to expand the production and raw material base, or technological and innovative development, but also the ratio of the use of own resources and borrowed investments [3, 4].

\section{Data}

The calculations used publicly available data. The data sources are: consolidated financial statements prepared in accordance with International Financial Reporting Standards (IFRS), as well as management analyzes of the company's financial condition and performance (in some companies - Management Reports) for the period 2010-2019.

1. Data on the main indicators (revenue, profit, assets, etc.) are presented for the industry based on the reporting of companies.

2. In the detailed breakdown of indicators by structure, open data were used for the 10 largest oil and gas companies, the total share of hydrocarbon production of which is more than $85 \%$ of the total production level of all Russian companies.

For a comprehensive study of the capital structure, in addition to building a model, it is necessary to analyze the current situation related to the volume and structure of the capital of Russian oil and gas companies. A distinctive feature of the oil and gas complex of Russia is the steady growth of the used equity and debt capital over the past 10 years. Thus, the amount of equity capital in the oil and gas complex from 2010 to 2019 grew almost 3 times to 33.6 trillion rubles, while debt capital increased more than 3.5 times to 20.4 trillion rubles in 2019 (Fig. 1).

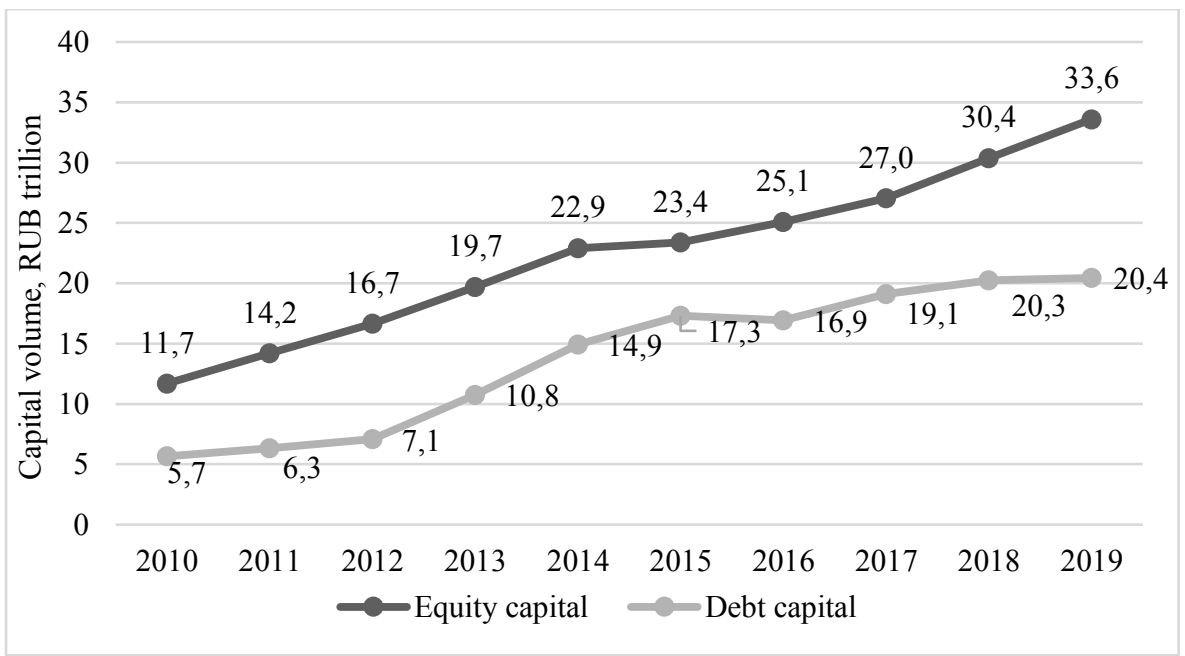

Fig. 1. Dynamics of equity and debt capital of companies in the oil and gas industry in Russia, trillion rubles.

Also, a feature of the Russian oil and gas industry is the preference to a greater extent of equity capital rather than borrowed funds. The share of equity capital exceeds the share of borrowed capital during the entire considered period from 2010 to 2019, which indicates 
the relative financial independence of the industry, as well as of individual companies in particular (Fig. 2).

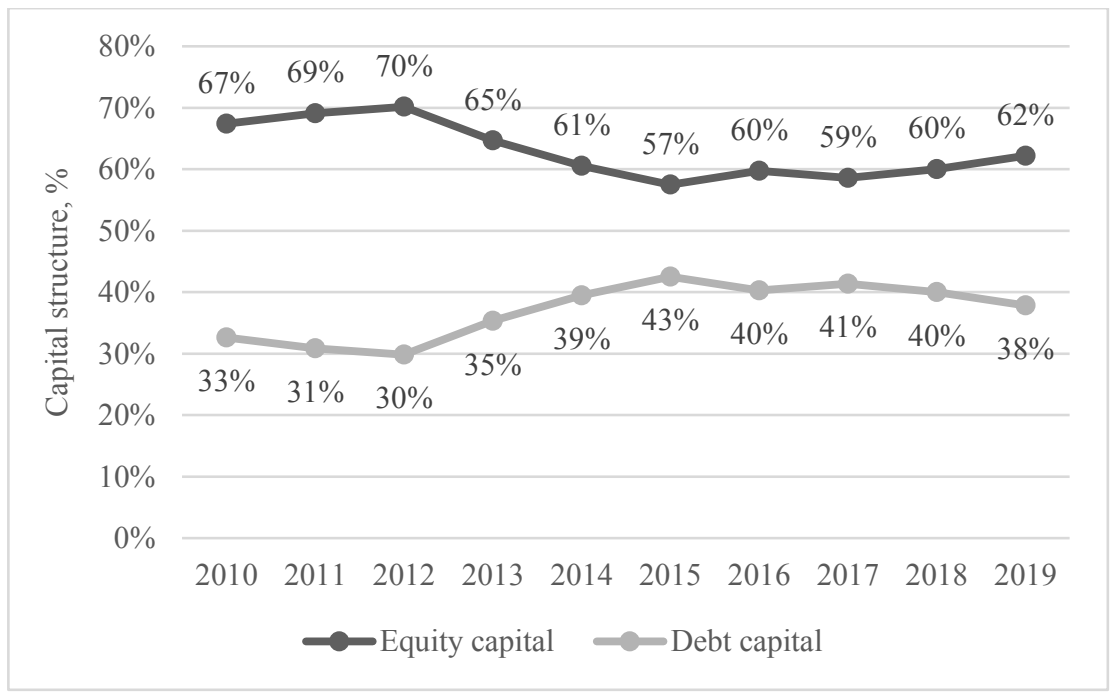

Fig. 2. Dynamics of the capital structure of companies in the oil and gas industry in Russia, \%.

At the beginning of the period under review from 2010 to 2013. the share of equity capital in the capital structure of Russian oil and gas companies exceeded $65 \%$, however, starting in 2014, the share of borrowed funds began to grow and the ratio between equity and borrowed capital remained at $60 \%$ to $40 \%$, a possible reason for this change was state financial support in the form of reduced interest rates, which affected the attractiveness of domestic loans. In recent years, there has been a slight increase in the share of equity capital in the structure to the level of $62 \%$ in 2019.

Among the Russian oil and gas companies, the 10 largest can be distinguished, each of which has unique features of development and strategies for the formation of the capital structure. An important component of the analysis of the capital structure is an understanding of the differences between the largest players of oil and gas companies of Russia in the field of attracting investments, therefore it is advisable to first analyze the capital structure of each of their Russian oil and gas companies over the past 10 years [5].

Among the oil and gas companies in Russia, Rosneft and Russneft stand out, since the strategies for raising capital in these companies are characterized by a large share of borrowed capital - more than $60 \%$ in the structure throughout the entire period under review. It is also important to note that over the past 4 years, the share of borrowed capital has been falling, which may indicate a change in strategy or the inability to borrow in the same amount due to unattractive lending conditions.

The opposite pole among Russian oil and gas companies is Lukoil, Surgutneftegaz and Novatek, with over $70 \%$ of their own funds in the capital structure. Throughout the entire considered period from 2010 to 2019. these companies preferred to attract their own sources of funding.

Gazprom Neft, Slavneft, Tatneft, Bashneft and Gazprom also have a larger share of equity capital than borrowed capital, however, these companies have more balance in financing sources in recent years, there is no significant deviation towards one of the sources of capital attraction, in contrast to the first two groups of companies with clear preferences for equity or debt capital. 


\section{Methods}

Analysis of the capital structure, its dependence on a number of factors, as well as the search for a rational capital structure is widely discussed in modern domestic and foreign literature. There are many approaches to analyzing the capital structure and finding the optimal balance. Finding a rational capital structure can occur both randomly and through purposeful choice. The most significant in the search for such a capital structure are quantitative methods that allow one to obtain estimates of the effective capital structure or to obtain the dependence of the capital structure on the financial and other indicators of the company's activity $[6,7]$.

A wide range of leading scientists in domestic and foreign literature devoted their research to the search for the optimal and effective ratio between own and borrowed funds, as well as substantiation of the factors affecting this ratio.

The literature discusses several approaches to determining and assessing the optimal capital structure of companies, which include optimization models, expert estimates, regression models, and panel data models.

The most common and convenient method for assessing the optimal capital structure is to build a panel data model. This method is widely used both in foreign and domestic works.

In the work of I.V. Ivashkovskaya and M.S. Solntseva 2008 carried out an econometric analysis of the capital structure using the example of panel data for 74 Russian companies. The analysis revealed the dependence of the capital structure of companies on a number of independent factors at the macro and micro levels [8].

E.S. Anoshkina and E.I. Markovskaya in 2018 also conducted a factor analysis of the capital structure by building a panel data model. The dependent variable was the indicator of financial leverage; the independent variables were the size of the company, growth potential, return on assets, production risk, and the dividend payout ratio [9].

In foreign works, the dependent variable in such a multivariate model is the leverage ratio [10], the ratio of borrowed and equity capital, the ratio of the total amount of borrowed capital to all assets of the company. The explanatory variables include earnings per share, company size and age, profitability, liquidity, and ratios that characterize the company's ownership structure.

Until now, there has been no consensus in the scientific literature on the approach to the choice of methods and criteria for determining the optimal ratio between own and borrowed funding sources. However, the methods of econometric analysis help to achieve the goal of finding the factors that are of fundamental importance on the capital structure. The construction of multivariate regression models and processing of panel data allows us to establish the significance of factors and determine the indicators that have a significant impact on the choice of certain sources of funding by the company [11, 12].

Based on an analysis of the works of domestic and foreign authors, as well as a study of the features of the activities of companies in the domestic oil and gas complex, allowed the authors to form a set of factors that have a fundamental impact on the capital structure. The set of factors covers a wide range of results of the financial and economic activities of oil and gas companies, including the size of companies, dividend policy, investment attractiveness, and a number of others (Table 1).

To exclude outliers and nonstationarity of variables that distort the results of building the model, the method of logarithm of variables was applied: the logarithm of the company's revenue was taken for the size of the company, and the logarithm of the company's market capitalization was used to assess the investment attractiveness. 
Table 1. Regressors selected to build a capital structure dependence model.

\begin{tabular}{|l|c|l|}
\hline \multicolumn{1}{|c|}{ Factor } & Designation & \multicolumn{1}{c|}{ Factor description } \\
\hline Company size & Size & Revenue of companies \\
\hline $\begin{array}{l}\text { Growth } \\
\text { potential }\end{array}$ & Growth & Growth in the company's assets for the year \\
\hline $\begin{array}{l}\text { Dividend } \\
\text { policy }\end{array}$ & DOE & $\begin{array}{l}\text { Dividend Payout Ratio } \\
\text { (Dividends Paid / Net Income) }\end{array}$ \\
\hline $\begin{array}{l}\text { Return on } \\
\text { equity }\end{array}$ & Gover & $\begin{array}{l}\text { State property - discrete variable } \\
\text { (1 is a state company, 0 is a private company) }\end{array}$ \\
\hline $\begin{array}{l}\text { State } \\
\text { participation }\end{array}$ & Risk & $\begin{array}{l}\text { Standard deviation of the company's revenue } \\
\text { for the last 3 years }\end{array}$ \\
\hline $\begin{array}{l}\text { Market } \\
\text { volatility }\end{array}$ & TrInt & $\begin{array}{l}\text { Share of proceeds from the sale of resources } \\
\text { and reserves on the international market }\end{array}$ \\
\hline $\begin{array}{l}\text { Diversification } \\
\text { of activities }\end{array}$ & Cap & Market capitalization of the company \\
\hline $\begin{array}{l}\text { Investment } \\
\text { attractiveness }\end{array}$ & &
\end{tabular}

To analyze the capital structure, the authors use a panel data model, which has some advantages over other models when analyzing the capital structure of oil and gas companies. Thus, a large number of observations increases the number of degrees of freedom, decreases the collinearity of independent variables, and as a result, we obtain more efficient estimates. Also, panel data makes it possible to control the heterogeneity of objects in the sample, as well as test effects that cannot be determined in cross-sections and in time series. To select the most appropriate specification when analyzing the dependence of the capital structure on various factors, the authors use the Hausman tests, the F-test, and the Brousch-Pagan test.

When studying domestic and foreign studies, the authors revealed that significant attention is paid to the choice of the optimal dependent variable that reflects the structure of the company's capital, such a variable can be the share of borrowed funds in the capital structure, the ratio of long-term liabilities to the company's equity capital, or the ratio of total liabilities to total assets. In this study, the dependent variable in the panel data model is the ratio of borrowed capital to equity, such a dependent variable was used both in the works of domestic and foreign researchers.

The equation for the panel data model looks like this:

$$
\begin{gathered}
\text { Debt }=\mathrm{a}+\mathrm{a}_{1} * \text { Size }+\mathrm{a}_{2} * \text { Growth }+\mathrm{a}_{3} * \text { Div }+\mathrm{a}_{4} * \text { ROE }+\mathrm{a}_{5} * \text { Gover }+\mathrm{a}_{6} * \text { Risk }+ \\
\mathrm{a}_{7} * \text { TrInt }+\mathrm{a}_{8} * \text { Cap }+\mathrm{f}_{\mathrm{i}}+\mathrm{v}_{\mathrm{t}}
\end{gathered}
$$

where Dept - the ratio of borrowed capital to equity, Size - the size of the company, Growth - the growth potential, Div - the dividend policy, ROE - the return on equity, Gover - government participation, Risk - market volatility, TrInt - the diversification of activities, Cap - the investment attractiveness, a - free variable, $a_{i}$ - coefficients of influence of factors on the dependent variable, $f_{i}-$ fixed effects for the $i$-th company, $v_{t}-$ random effects for time t.

For the study, the following stages of work were identified: selection of data on the dependent variable and selected factors for companies in the oil and gas industry of Russia for the period 2010-2019, conducting tests for endogeneity, data balance, checking the correlation between factors. To build a model of the dependence of the capital structure on 
a number of selected regressors, 3 specifications were built: a basic panel data model for the entire period, a panel data model with fixed effects, and a panel data model with random effects. To select the best specification, the F-test, the Hausmann test and the Brousch-Pagan test are performed. In addition to considering 3 specifications of the panel data model for the period 2010-2019. the authors examined the impact of sanctions on the strategy of forming the capital structure by dividing the period under consideration into two time periods: 2010-2014. and 2015-2019 For these periods of time, three models of panel data of various specifications were also built, and using the tests listed above, the most appropriate ones were selected to explain the change in the capital structure.

To analyze the capital structure, identify significant factors and build a panel data model, the following indicators were chosen: the ratio of borrowed capital to equity is used as a dependent variable, and a number of economic indicators were selected as independent variables: company size, growth potential, dividend payments, profitability of equity. capital, standard deviation of revenue, market capitalization of companies and share of revenue from international shipments.

\section{Results}

Based on the selected factors, the authors built models based on panel data. The analysis included the 10 largest oil and gas companies in Russia, for each selected indicators were collected for the period from 2010 to 2019. For each period, 3 specifications were built: a basic panel data model, a fixed effects model, and a random effects model.

Based on the p-value, the Hausman, Brousch-Pagan tests and the F-test, the most appropriate and significant specifications were selected: a random effects model for the period 2010-2019, a fixed effects model for the period before the imposition of sanctions, and a base model for the period. after the imposition of sanctions. Next, we will consider each of the selected specifications to identify important results.

\subsection{Random effects model for the period 2010-2019}

Table 2 presents the results of the random effects model, which is the best specification for the period 2010-2019, the significant factors in this model are company size, return on equity and the share of revenue from international shipments. The size of the company, as in all the considered specifications in this period, has a positive effect on the share of borrowed capital in the structure, the return on equity and proceeds from international supplies have a negative effect, with an increase in these indicators, companies reduce the share of debt capital in the structure.

Table 2. Results of building a panel data model

\begin{tabular}{|l|c|c|c|}
\hline \multicolumn{1}{|c|}{ Metric } & $\begin{array}{c}\text { PD model with } \\
\text { random effects for the } \\
\text { entire period }\end{array}$ & $\begin{array}{c}\text { Fixed Effects PD } \\
\text { Model Before } \\
\text { Sanctions }\end{array}$ & $\begin{array}{c}\text { Basic PD model } \\
\text { after the imposition } \\
\text { of sanctions }\end{array}$ \\
\hline Free coefficient & 0,662 & $\mathbf{1 . 3 8 3} * * *$ & $\mathbf{- 0 . 4 3 1 * *}$ \\
\hline Company size & $\mathbf{0 . 2 8 7}$ & $\mathbf{- 0 . 9 7 * * *}$ & 0.411 \\
\hline $\begin{array}{l}\text { Growth rate of } \\
\text { company assets }\end{array}$ & -0.291 & $\mathbf{- 0 . 0 0 0 3 * *}^{*}$ & 0.000002 \\
\hline $\begin{array}{l}\text { Standard } \\
\text { deviation of } \\
\text { revenue }\end{array}$ & -0.0001 & & \\
\hline
\end{tabular}




\begin{tabular}{|c|c|c|c|}
\hline Dividend policy & & $-0.172 *$ & \\
\hline ROE & $-0.957^{*}$ & -0.701 & -0.271 \\
\hline $\begin{array}{l}\text { Revenue from } \\
\text { international } \\
\text { deliveries }\end{array}$ & -0.011 . & -0.006 & $-0.013 *$ \\
\hline Capitalization & -0.124 & $-0.869 * * *$ & $0.311 * *$ \\
\hline $\mathrm{R}^{2}$ of the model & 0.229 & 0.87 & 0.55 \\
\hline $\begin{array}{l}\mathrm{p} \text {-value of the } \\
\text { model }\end{array}$ & 0.009 & 0.000 & 0.014 \\
\hline F-test & $\begin{array}{l}\text { P-value }=0.99>0.05 \text {, this } \\
\text { means we accept the } \\
\text { hypothesis of equality of } \\
\text { all fixed effects and it is } \\
\text { better to use the } \\
\text { conventional model than } \\
\text { with fixed effects. }\end{array}$ & $\begin{array}{l}\text { P-value }=0.042 \text {, this } \\
\text { means that the fixed } \\
\text { effects model is better } \\
\text { than the base model in } \\
\text { our case. }\end{array}$ & $\begin{array}{l}\text { P-value is equal } 0.398 \text {, } \\
\text { means base model is } \\
\text { better than fixed effects }\end{array}$ \\
\hline Hausman test & & $\begin{array}{l}\text { Hausman test, which } \\
\text { allows you to choose } \\
\text { between a model with } \\
\text { random effects and with } \\
\text { fixed: p-value of the test } \\
=2.2 \mathrm{e}-16 \text {, which means } \\
\text { it is better to use a } \\
\text { model with fixed } \\
\text { effects. }\end{array}$ & \\
\hline $\begin{array}{l}\text { Brousch-Pagan } \\
\text { test }\end{array}$ & $\begin{array}{l}\text { P-value in the test }= \\
8.103 \mathrm{e}-10<0.05 \text {, so we } \\
\text { reject the null hypothesis, } \\
\text { which means that the } \\
\text { residuals } \\
\text { heteroscedastic, are } \\
\text { variances are not equal, so } \\
\text { the model with random } \\
\text { effects is the most } \\
\text { preferable. }\end{array}$ & $\begin{array}{l}\text { Brousch Pagan test, } \\
\text { which allows you to } \\
\text { choose between the base } \\
\text { model and the model } \\
\text { with random effects: p- } \\
\text { value = } 0.059 \text {, which } \\
\text { means it is better to use } \\
\text { the base model than the } \\
\text { model with random } \\
\text { effects. }\end{array}$ & \\
\hline
\end{tabular}

Note: - significance at the $10 \%$ level, ${ }^{*}$ - significance at the $5 \%$ level, ${ }^{* *}$ - significance at the $1 \%$ level, *** - significance at the $0.1 \%$ level.

Source: calculated by the authors

The positive impact of company size on the share of borrowed capital of oil and gas companies in Russia is explained by the specifics of legislation and government assistance in Russia: large companies are more likely to receive licenses for the development of fields, receive benefits and special borrowing conditions, which makes borrowed sources of financing more attractive for large oil and gas companies. than for small companies.

The return on equity, of course, has a negative impact on the share of borrowed capital, since the higher the return on equity, the higher the return on own sources of financing, the more profitable they are for attracting the company to carry out its activities. The growth in the share of proceeds from international supplies also has a negative impact on the share of borrowed capital, which may indicate some norms for entering the international market, with the attraction of a larger amount of own funds, as a guarantee of the stability and sustainability of the oil and gas company. 


\subsection{Panel data models considering the impact of sanctions}

In addition to the considered basic models, models with fixed and random effects with selected explanatory factors, it is assumed that for the considered period from 2010 to 2019. The macroeconomic situation in Russia has changed significantly, the imposed sanctions could significantly affect the strategies and capabilities of Russian oil and gas companies to attract debt and their own sources of financing.

However, the question arises about the possibility of applying the variable sanction in the model. Due to the problem of multicollinearity, we will not be able to use the variable sanctions as one of the regressors, the way out in this situation can be the construction of two models, we will divide the considered period into two time periods: from 2010 to 2014 . and from 2015 to 2019. Thus, starting in 2015, companies could feel the impact of the sanctions on their activities and the possibility of raising funds for the company.

For the pre-sanctions period, the fixed effects model turned out to be the best specification. This model is significant and explains well the capital structure, since the R2 of the model $=0.87$. In this model, the size of the company, the growth rate of assets, the standard deviation of revenue, capitalization, and dividend policy were all significant. The size of the company, similar to the model with random effects for the entire period, has a positive effect on the share of borrowed capital, and other significant indicators with growth lead to a decrease in the share of borrowed capital.

For the period during the sanctions, similar models were built and significant factors identified. When constructing a basic model of the dependence of the capital structure, it turned out that the most significant indicators are the size of the company, the share of proceeds from international supplies and capitalization. All factors have a negative impact on the share of borrowed capital, except for capitalization. The negative direction of the impact of the size of the company on the share of borrowed capital may indicate the consequences of the imposed sanctions: the main "blow" fell on the largest companies in the industry, they no longer have the opportunity to borrow abroad on favorable terms and, accordingly, the next option for attracting capital to the company is their own funds ... The share of proceeds from international supplies continues to grow with an increase in the share of equity capital as a guarantee of the stability and stability of Russian companies, and the capitalization of the company increases the attractiveness and demand for the company with growth, which may be an indirect reason for providing more favorable conditions to the largest borrowers, which are oil and gas companies.

Thus, the period before the imposition of sanctions is characterized by a significant negative impact on the share of borrowed capital from the growth rate of assets (which occurred during this period due to the increase in equity capital), dividend policy (the more funds the company spent on dividend payments, the greater the share of equity capital in the total capital of the company), capitalization (the more expensive the company's shares were, the greater the share of equity in the company's capital), fluctuations in revenue also had a slight negative impact (the higher these fluctuations, the smaller the share of borrowed funds). Only the size of the company showed a positive effect on the share of borrowed capital (the larger the company, the more it attracts borrowed funds, which was feasible due to the access of Russian oil and gas companies to foreign credit markets). For the period after the imposition of sanctions, directly during their impact on Russian oil and gas companies, the size of the company has a significant impact on the debt-to-equity ratio (negatively affects the share of borrowed capital during the company's growth), revenue from international supplies (also, the higher the share of proceeds from supplies to the international market, the higher the share of own funds attracted to the company) and capitalization (now, the higher the value of the company, the more borrowed funds are attracted as a source of financing). 


\subsection{Discussion}

Capital, of course, is the most important component in the company's activities, making it possible to carry out activities, acquire assets and manufacture products. At present, due to strong external and internal challenges to the sustainable development of the oil and gas complex, the issue of increasing investments in the industry has become especially acute. At the same time, it is necessary to accurately assess what funds will be used to finance borrowed or own.

Russian oil and gas companies show a significant difference in their financing strategies, for example, Rosneft's activities are largely carried out at the expense of borrowed funds (more than $70 \%$ in the structure), and Novatek uses more than $80 \%$ of its own funds for operation. Based on the study, it was revealed that the most significant indicators that determine the capital structure of oil and gas companies in Russia are company size, return on equity and revenue from international supplies. Moreover, with an increase in the size of the company, the share of borrowed capital in the structure also grows, since favorable lending conditions become available for the largest companies, and with an increase in the return on equity and the share of proceeds from international supplies, the share of equity capital grows as a guarantor of the stability and reliability of the company. the world market.

When shaping the capital structure of oil and gas companies in Russia, it is necessary to take into account the size of the company, the return on equity and focus on the international market. There are two polar strategies for the largest companies: with significant government support and focus on mining on the shelf and in the Arctic and a high share of supplies to the international market, it is advisable to give preference to borrowed capital, as Rosneft does. If the largest companies operate in fields in the country, without access to the continental shelf and in hard-to-reach fields, while they have a low return on equity and are focused on international supplies, it is necessary to give preference to equity when carrying out activities (about $70 \%$ in the capital structure). For mediumsized companies, the focus on international supplies, offshore operations and return on equity is also significant: if the company has a high return on equity and operates on the continental shelf, it is necessary to give preference to equity capital, if the company operates on fields in the regions of Russia and has a uniform structure of supplies to international and domestic markets - when choosing sources of financing, it is necessary to strive for a more even structure of capital.

\section{Conclusion}

In modern scientific literature, several approaches to the study of the capital structure and the principles of its formation are widely used: expert assessments, linear programming methods, as well as econometric analysis, which allows us to identify the factors that influence the dependent variable.

The authors used stochastic factor analysis in the study, in which the ratio of borrowed capital to equity capital was used as a dependent variable. The regressors were various economic indicators characterizing the characteristics of each oil and gas company: company size, growth potential, dividend policy, return on equity, standard deviation of revenue, share of revenue from sales of raw materials on the international market and company capitalization.

Also, in addition to the selected factors, the authors considered the impact of sanctions on the capital structure of Russian oil and gas companies by dividing the period under consideration into two: before the introduction of sanctions and during their operation. Thus, before the imposition of sanctions, the size of the company had a positive effect on 
the share of borrowed capital in the structure, and the growth rate of assets, fluctuations in revenue, dividend policy and capitalization, while increasing, reduced the share of borrowed capital. After the imposition of sanctions, the picture has changed; the size of the company is now acting in the opposite direction: as the size of the company increases, it increasingly gives preference to equity capital over debt. Capitalization after the imposition of sanctions now has a positive effect on the share of borrowed capital, and the share of proceeds from international supplies, with its growth, leads to an increase in the share of equity capital.

Based on the results obtained, in the future, it is advisable to expand the base of factors influencing the capital structure by adding all kinds of risks, conditions and sources of attracting both borrowed and equity capital, the specifics of the company's work, as well as a separate component of the work can be the determination of the optimal ratio of borrowed and own capital for the largest oil and gas companies in Russia, taking into account individual economic, managerial and strategic characteristics.

The study was carried out with the plan of research work of IEIE SB RAS, project 121040100281-8 "Methods and models of justification of strategy...".

\section{References}

1. L. Eder, et al., E3S Web of Conferences, 80 (2019)

2. I.V. Filimonova et al., Energy, 6, 27-31 (2020)

3. L.V. Eder, I.V. Provornaya, I.V. Filimonova, Geography and Natural Resources, 40 (1), 9-14 (2019)

4. S.M. Nikitenko, E.V. Goosen, IOP Conference Series: EES, 53 (1), (2017)

5. S.M. Nikitenko, M.A. Mesyats, IOP Conference Series: MSE, 253 (1) (2017)

6. I. Sharf, Economic of Region, 2, 628-640 (2017)

7. I. Sharf et al., IOP Conference Series: EES, 27 (1), (2015)

8. I.V. Ivashkovskaya, M.S. Solnceva, Saint Petersburg University Bulletin, 8 (3), 3-32 (2008)

9. E.S. Anoshkina, E.I. Markovskaya, Economic policy, 13 (5), 80-109 (2018)

10. S. Kasthury, S. Anandasayanan, Vavuniya campus international research symposium, Impact of firm specific factors on capital structure: evidence from listedcompanies in Colombo stock exchange of Sri Lanka, 13-20 (2019)

11. A.B. Elmurzaeva, Russian entrepreneurship, 5 (2), 90-93 (2010)

12. V.N. Volobuev, Scientific notes of the Russian State Social University, 1 (77), 118-122 (2010) 